\title{
Obstacles Facing Promoting Tourism for Islamic Landmarks from the Perspective of Tour Operators in Egypt
}

\author{
Suzan Bakri Hassan \\ Department of Tourism Studies, Faculty of tourism and Hotels, Fayoum University, Egypt
}

\begin{abstract}
The UNESCO launched a campaign \#unite4heritage in Egypt to defeat extremism and intolerance. The message of such campaigne is peace, dialogue and unity embedded in cultural heritage. As culture and tourism are linked together, such message could be delivered through improving culture heritage tourism in Egypt. Islamic landmarks are considered as a part of human heritage. Therefore, the purpose of this study is to identify how much tour operators in Egypt include Islamic landmarks in their programs to determine the obstacles facing promoting cultural tourism in Islamic landmarks' areas. Additionally, the study would identify positive results in the case of developing heritage tourism in Egypt. To achieve a high result, a survey approach was employed to collect data from 100 tour operators, using a completed questionnaire technique as well as a Likert Scale and statistical models in order to test and interpret the research outcomes. The research findings indicated that although tour operators in Egypt are convinced of the significance of the Islamic landmarks, there is no contradiction between creating global understanding and at the same time achieving benefit to the local community. However, there is a range of obstacles facing promoting such type of tourism in Egypt.
\end{abstract}

Keywords: Culture heritage tourism, community, Egypt, Islamic civilization.

\section{INTRODUCTION}

The travel and tourism sector has become an important driver of growth and prosperity for many countries. It is estimated that this sector accounts for about 9 percent of GDP and employment worldwide (Insight report, 2012). Nowadays the requirements and expectations of tourists as well as the concept of tourism have changed. As an alternative to the concept of tourism based on entertainment and resting, the cultural tourism has developed helping tourists and hosts communities to contact with each other and foster understanding and experiences between them [1].

According to the UNWTO $37 \%$ of all tourism trips contain a cultural element; in its forecast 2020 UNWTO predicts that cultural tourism will be one of the 5 key market segments of the future. ATLAS survey also indicates a further growth in the proportion of tourists taking cultural holidays, up from $17 \%$ in 1997 to $31 \%$ in 2007 which means that cultural tourism is growing in importance worldwide [2].

As a matter of fact, the Egyptian economy relies heavily on tourism sector. Egypt receives mostly mid and low spending tourists as well as a small number of high spending tourists. With the increasing demand for unique experiences,

\footnotetext{
* Correspondence address:

Suzan Bakri Hassan

Email : suzzanbakri@yahoo.com

Address : Dept. of Torism, Faculty of Tourism and Hotels, Fayoum University, Egypt
}

boards of tourism and DMOs will be forced to present on different markets [3] by diversing the tourist attractions in order to achieve a balanced growth of the tourism industry and maximum benefit. This means that the type of tourism products developed and the facilities that support them must be able to attract visitors that are prepared to pay a premium price as heritage/ culture tourists. The success of such an approach depends heavily on the quality of the overall visitor's experience since the time of arrival to the time of departure.

Additionally, Egypt is predominantly perceived of as the land of the Pharaohs. However, the Pharaonic era is only one component of Egypt's rich and diverse history. Egypt bears witness to the histories of civilizations, such as the Greeks and Romans, and also the expansion of ideologies, such as the Christian and Islamic. Many heritage regions in Egypt are still waiting for serious planning treatment. For example, the whole area of Islamic Cairo needs to be planned and included in tourists' programms as a part of the tourism product [4]. This study aims to identify how much tour operators in Egypt include Islamic landmarks in their programs in order to determine the obstacles facing promoting culture tourism in these areas from their point of view, and to identify the positive results in the case of its development. 


\section{TOURISM IN EGYPT}

\section{Culture Heritage Tourism}

Tourism is not just an aggregate of merely commercial activities; it is also an ideological framing of history, nature and tradition; a framing that has the power to reshape culture and nature to its own needs [5]. Many destinations developed their tangible and intangible cultural assets as monuments, museums, theme parks, architectural and artistic works or sculptures or events as cultural historical events, music and dance, theater, language and literature, festivals and artistic events and put them on show for tourists stepping beyond the sun, sea and sand tradition for a 'real' taste of their host destination through cultural heritage tourism $[1,6]$.

Culture heritage tourism helps destinations in developing comparative advantages in an increasingly competitive tourism marketplace. It also helps creating local distinctiveness in the face of globalisation. Although there is no single agreed definition for culture tourism and heritage tourism. However Stebbins [7] defines culture tourism as a genre of special interest tourism based on the search for and participation in new and deep cultural experiences, whether aesthetic, intellectual, emotional, or psychological. Cultural tourism also regarded as a form of special interest tourism where culture forms the basis of either attracting tourists or motivating people to travel [8-11].

Similarly, heritage tourism is regarded as a subclass of cultural tourism, which is defined by the World Tourism Organization [12] as "movements of persons for essentially cultural motivations such as study tours; performing arts and cultural tours". Heritage tourism is based on nostalgia for the past and the desire to experience diverse cultural landscapes and forms [13]. In addition, cultural heritage tourism defined as "traveling to experience the places and activities that authentically represent the stories and people of the past and present. It includes historic, cultural and natural resources [14]. Heritage tourism employs historic-assets, cultural and natural resources that already exist rather than creating and building attractions, and destinations look to the past for a sustainable future. Indeed these assets need preservation and often restoration or interpretation, but the foundation for creating a dynamic travel experience lives on in the stories and structures of the past [15]. The term "cultural heritage tourism" is useful to help bring together all of the partners that need to be working together on this type of an effort including organizations [16]. In this study, both heritage and cultural tourism are used in combination and/or interchangeably.

\section{Culture Heritage Tourism for Dialogue between Civilization}

The relationships and interaction between cultures and civilizations through dialogue considered as a major force of development and progress. Culture Heritage tourism is a major vehicle of the ongoing dialogue between differnet civilizations. It helps promoting true knowledge of the divine religions and reemerging ignorance in order to understand and learn from and about others and their experiences without any prejudices or preconceived ideas. This dialogue is a necessity in the contemporary world and should be rooted in the hearts and mind of people in order to overcome obstacles.Such dialogue must focus on the signinficance of shared values which give meaning to life and provide form and substance to identities. Tolerance and respect for the other are core values that transcend civilization differences [17].

Consequently, cultural heritage proves its signicance within the context of peace. It is often the denial of cultural identities that fuels the countless conflicts afflicting the globe, and that prepares and foments the conflicts of the future. The central element of the culture-of-peace idea is an understanding of the identities of others [18] to break down political and ideological barriers [19] through ensuring the accessability of culture heritage to all visitors [4]. Culture heritage tourism is a necessity to empower people with a deep awareness of areas such as their own history and heritage.

\section{Islamic Landmarks in Egypt}

The Islamic Civilization is in reality resembles an amalgam of a wide variety of cultures from North Africa to the western periphery of the Pacific Ocean, and from Central Asia to subSaharan Africa. Interesting archaeological sites for the Islamic civilization include Qandahar (Afghanistan), Samarra (Iraq), Qusayr' Amra (Jordan), Aqaba (Jordan), Shanga (Kenya), al Rafiqa (Syria) and Hamdallahi (Mali), al-Fustat (Egypt), Siraf Mosque (Iran), Baghdad, Husn alQadisiyah, Jundi Shapur, Kufa, Ukhaidir (Iraq), Aqaba (Jordan) [20], all witness the Islamic civilization.

It is obvious that the spirit of Islam and the culture of the Arabs swept over all the old part of 
Egypt. The influence of the Islamic and Arab culture and architecture was so pervasive that the Egyptian cities and towns became pioneers, leading Muslims and countries in many ages [21]. More than two hundred Islamic monuments covering less than two square hectares, still stand today in Cairo. Cairo's architectural monuments rank among humanities great achievements recognizing that their preservation is a matter of importance to the whole world. The UNESCO has listed the Egyptian capital Cairo as one of the cities of human heritage. Such recognition is well justified for few cities on the earth display and a dense concentration of historic architectural treasure as does Cairo. This concentration reflects the political situation of Islamic Egypt which never had another capital outside the space occupied by the city tha is called Cairo. However, historians describe a series of capital cities, including Al Fostat, Al Askar and Al Qataiia and Al Qahira, but all of these were within sight of one another and eventually became a single city Cairo has been the center of power in Egypt since the year 641. Continuously, centralized power in one area distinguishes Egypt from other Islamic nations, such as Syria, Iraq, Anatolia, Andalusia and Persia. The area between the mosque of Amr in the south and Bab al-Nasr and Bab al Futuh to the north out side this area where there is a few medieval buildings of interest have survived, on one hand. On the other hand, there is a large number of Egypt's medieval and post-medieval monuments still stand within it just to witnesses more than eleven centuries of history [22].

The Muslim landmarks in Egypt are divided into eight periods. Each period was distinguished by its architectural perspective and left a rare collection of antiquities, architecture and graphics as follows.

Table 1. Islamic landmarks period in Eqypt

\begin{tabular}{|c|c|c|}
\hline Period & Landmarks & Year \\
\hline The Orthodox Khalifs period & The Mosque of Amr Ibn Elas & $21 \mathrm{H}(642)$. \\
\hline $\begin{array}{l}\text { The Tulunid period } \\
254-292 \mathrm{H} .(868-905 \text { AD) }\end{array}$ & The Mosque of Ahmed Ibn Tulun & $263-65$ H (876/877-879) \\
\hline The Fatimid period & Al- Azhar Mosque & 359- 61H.(970-72) \\
\hline \multirow[t]{6}{*}{358 - 567 H. (969-1171 AD) } & Mosque of Al- Hakim & 380- 403Н.(990- 1013) \\
\hline & Mosque of Al-Guyushi & $478 \mathrm{H} .(1085)$ \\
\hline & Al- Aqmar Mosque & 519H.(1125) \\
\hline & Mashhad (Mausoleum) of As-Saiyida Ruqaiya & 527H. (1133) \\
\hline & Mosque of Sayidina Al-Husayn & $549 \mathrm{H} .(1154 / 55)$ \\
\hline & Mosque of As-Salih Talat & $555 \mathrm{H} .(1160)$ \\
\hline The Aiybbid period & Mausoleum \& Mosque of Imam Ash-Shafit & $608 \mathrm{H} .(1211)$ \\
\hline \multirow[t]{3}{*}{$567-648$ H. (1171-1250 AD) } & Mosque of Sultan As-Salih Negm Ad -Din & 647/48H. (1249/50) \\
\hline & The Salihiya Madrasa & $641 \mathrm{H}(1243 / 44)$ \\
\hline & Mausoleum of Sultan Sultan As-Salih Negm Ad-Din & $647 / 48 \mathrm{H} .(1249 / 50) \mathrm{s}$ \\
\hline The Mamluk period & Mosque of Sultan Az-Zahir Baybars & $665-67 H(1267-69)$ \\
\hline \multirow[t]{5}{*}{648 - 923 H. (1250-1517 AD) } & Mosque-Madrasa-mausoleum of Sultan Qalaun & 683- 684H.(1284-85) \\
\hline & Mosque \&Madrasa of An-Nasir Muhammad Ibn Qalaun & 695- 703H (1295-1304) \\
\hline & Mosque of Salar and angar Al-Gawli & $703 \mathrm{H}(1303 / 1304)$ \\
\hline & Khanqa of Sultan BayBars al-Gashankir & $709 \mathrm{H}(1310)$ \\
\hline & Mausoleum of Hasan Sadaqa & $715 \mathrm{H} .(1315)$ \\
\hline The Ottoman period & Mosque of Sulayman Pasha & 935H.(1528) \\
\hline \multirow[t]{5}{*}{923 - 1220 H. (1517-1805 A.D.) } & Mosque of Al Hamudiya & $975 \mathrm{H}(1567)$ \\
\hline & Mosque of Sinan Pasha & $979 \mathrm{H}(1571)$ \\
\hline & Mosque of Al-Malika Safiya & 1019H.(1610) \\
\hline & Mosque of Al-Burdaini & $1025-1038 \mathrm{H}(1616-1629)$ \\
\hline & Mosque of Muhammad Bey Abu Adh-Dhahaba & $1188 \mathrm{H}(1774)$. \\
\hline Muhammad Ali period, & Mosque of Hasan Pasha Tahir & 1224H. (1809) \\
\hline \multirow[t]{2}{*}{$1220-1265$ H. (1805- 1848 AD) } & Mosque of Muhammad Ali Al-Kabir & $1246-1265 \mathrm{H} .(1830-1848)$ \\
\hline & Mosque of Sulayman Agha As-Silihdar & 1253- 1255H (1837- 1839. \\
\hline \multirow[t]{6}{*}{ The Modern period } & Mosque of As-saiyida Zaynab & $1302 \mathrm{H} .(1884 / 85)$ \\
\hline & Mosque of As-Saiyida Nafisa & $1314 \mathrm{H}(1897)$ \\
\hline & Mosque of Ar-Rifaii & $1329 H(1911)$ \\
\hline & Mosque of Al-Fath & $1338 \mathrm{H}(1920)$ \\
\hline & Mosque of Dumaqsis & $1116 \mathrm{H}(1704)$ \\
\hline & Mosque of Al -Fuli & \\
\hline
\end{tabular}


There is a number of other Islamic buildings, such as the citadel of Salah Al-Din, the Walls of Cairo, Beit al-Kreitleya, Beit Gamal al Din al Zahabi, Beit al-Sehiemi, Wikalet al-Ghouri, Khan Khalili Bazar, the Islamic arts Museum, the Manial palace Museum, the Nilometer at Roda, Sabil-Kuttab of Abd El-Rahman Katkhuda, the Fort of Qait Bay, and the Fortress of Salah al-Din on Pharaoh's Island.

\section{MATERIALS AND METHODS}

Tour operators play a vital role in the tourism industry. As intermediaries between tourists and tourism service providers, tour operators can influence the choices of consumers, the practices of suppliers and the development patterns of destinations [23]. The purposes of this study are to investigate whether or not tour operators in Egypt well include Islamic sites in their tourism programs as well as identify the obstacles facing the development of the heritage tourism in these sites. Additionally, the study would determine the benefits in the case of developing it. To achieve the objectives and hypotheses of this study, the study methodology depends on questionnaires with 24 questions that were distributed among 100 tour operators in Cairo and Giza governorates.

The response rate reached $70 \%$. Most of the non-respondent organizations mentioned many reason such, they are not ready to deal with questionnaire; they are too busy, these data are confidential, etc. Literature, site visits, and interviews used to formulate conclusions and recommendations to define obstacles facing developing Islamic landmarks in Egypt. The Likert scale was used to analyze officials responsible and experts towards the objectives of the study by answering a number of questions using fivepoint scale '5-1 (strongly agree - strongly disagree'. Statistical models were used to analyze the data.

\section{RESULTS AND DISCUSSION}

All of the respondents asserted that heritage tourism is available in Islamic landmarkes. Total $58 \%$ of the respondents asserted that Islamic sites are included in tourism programs as half day tours while $42 \%$ of them see that it is not included (Fig.1).

Although visitor's services encompass the basic elements, most travelers need to make traveling more enjoyable such as shopping, touring, lodging, restaurants, and infrastructure [24] and that consumer are increasingly considering environ-mental quality as well as the quality of services as factors in their selection of tourist destinations.

islamic Sites in tourism programe

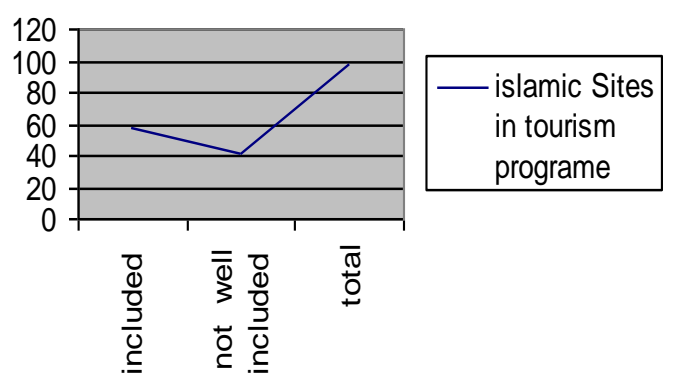

Figure 1. Islamic Sites in tourism Programe

Additionally, they want a high standard of environmental conservation coupled with simple, efficient and pleasant service [25] but, the results in Table 1 indicate the agreement of most respondents on the lack of services and tourism facilities in selected areas.

In addition, about $74 \%$ of the respondents disagreed to the availability of good transportation services, Mean-1.99. Total $91 \%$ of the respondents disagreed to the availability of information on things to do and not to do, Mean1.43. As much as $77 \%$ of the respondents disagreed to the Cleanliness of the local environment and $77 \%$ of the respondents disagreed to the availability of cleaning bathing areas, Mean-1.97. It is clear from results that most of Islamic landmarks areas are suffering from the lack of services. The respondents also mentioned that most of these areas existe in a slum areas and there is a lack of role of the Ministry of Culture in raising public awareness.

Results in Table 2 shows the agreement of most respondents about the lack of effective marketing Strategies to promote tourism in Islamic landmarks areas and they does not believe that there is neither a marketing plan to promote tourism, nor an adequate development plan. Other obstacles mentioned by respondents were lack of using modern tecnology in publicity, lack of such information about these places and neglecting domestic tourism. 
Table 2. Tourism services in Islamic landmarks' areas

\begin{tabular}{|c|c|c|c|c|c|c|c|c|c|c|}
\hline & $\begin{array}{c}\text { Strongly } \\
\text { disagree } \\
(\%)\end{array}$ & $\begin{array}{l}\text { Disagree } \\
(\%)\end{array}$ & $\begin{array}{l}\text { Neutral } \\
(\%)\end{array}$ & $\begin{array}{c}\text { Agree } \\
(\%)\end{array}$ & $\begin{array}{c}\text { Strongly } \\
\text { agree } \\
(\%)\end{array}$ & Mean & $\begin{array}{l}\text { Std. } \\
\text { Error }\end{array}$ & $\begin{array}{l}\text { Std. } \\
\text { Dev }\end{array}$ & $\begin{array}{l}\text { Chi - } \\
\text { Square }\end{array}$ & Sig. \\
\hline $\begin{array}{l}\text { transport services in } \\
\text { the destination }\end{array}$ & 39 & 35 & 12 & 12 & - & 1.99 & .121 & 1.007 & $16.159 a$ & .001 \\
\hline $\begin{array}{l}\text { places to eat and } \\
\text { drink }\end{array}$ & 32 & 36 & 12 & 12 & 6 & 2.23 & .143 & 1.190 & $24.406 b$ & .000 \\
\hline $\begin{array}{l}\text { information on } \\
\text { things to do in the } \\
\text { destination }\end{array}$ & 68 & 23 & 3 & 3 & -- & 1.43 & .089 & .737 & $75.058 a$ & .000 \\
\hline $\begin{array}{l}\text { availability of health } \\
\text { services }\end{array}$ & 35 & 39 & 13 & 13 & 4 & 2.13 & .140 & 1.162 & $34.696 b$ & .000 \\
\hline $\begin{array}{l}\text { cleanliness of the } \\
\text { local environment }\end{array}$ & 47 & 30 & 10 & 10 & 4 & 1.96 & .141 & 1.169 & $43.971 b$ & .000 \\
\hline clean bathing areas & 42 & 35 & 7 & 7 & 4 & 1.97 & .134 & 1.111 & 40.783b & .000 \\
\hline directional Signs & 25 & 29 & 28 & 28 & 6 & 2.61 & .155 & 1.286 & $14.116 \mathrm{~b}$ & .007 \\
\hline shopping & 18 & 25 & 20 & 20 & 4 & 2.70 & .134 & 1.115 & $15.565 b$ & .004 \\
\hline $\begin{array}{l}\text { awareness among } \\
\text { the local } \\
\text { community }\end{array}$ & 17 & 39 & 7 & 7 & 3 & 2.39 & .115 & .958 & $34.696 b$ & .000 \\
\hline
\end{tabular}

Additionally, $54 \%$ of the respondents do not believe that there is neither a marketing plan to enhance tourism in Islamic landmarks areas, nor an adequate publicity about these areas, on one hand. On the other hand, 33\% are neutral as they do not have any information about any strategies to develop these areas, Mean -2.48 . Total $45 \%$ of the respondents (13\% strangely disagree, 32\% disagree) about the existing of a plan to manage and develop Islamic landmarks'areas for tourism and $36 \%$ was neutral, Mean-2.65. This outcome does not match the standered of developing heritage tourism in religious areas as tourism at religious or sacred sites is a special type of cultural heritage tourism [26]. Developing cultural heritage at religious sites requires a plan in which all stakeholders participate taking intoconsideration allowing the local community to continue using the site; and prreservation of it.

The results in Table 3 show that the majority of the respondents agreed to the positive results in case of developing heritage tourism as follows:

About $90 \%$ of the respondents asserted that there would be economic benefits to local community, mean -1.49 . Total $85 \%$ of the respondents see that tourism in these areas will be Competitive value Mean -1.55 , on one hand. On the other hand, $85 \%$ of the respondents agreed on the importance of tourism development in these areas to create a dialogue among civilizations, mean-1.81. In addition, 86\% of the respondents asserted that developing tourism in these areas will be a tool for
Preserving local traditions and culture, mean 1.65. It is also worht mentioned that $84 \%$ of the respondents asserted that tourism in these areas would increase awareness of the site or area's significance, mean -1.93.

Consequently, cultural resources generate economic vitality by leveraging human capital and culture to generate economic vitality through tourism, crafts, and cultural attractions. Programs based on such resources can improve urban quality of life, and expand business and tax revenue base and positive regional and community image [27]. Heritage tourism protects historic, cultural, and natural resources in towns and cities by involving people in their community. When they can relate to their personal, local, regional, or national heritage, people are more often motivated to safeguard their historic resources. Culture heritage tourism can be employed as a tool for raising awareness as it educates residents and visitors about local and regional history and shared traditions. Through involvement and exposure to local historic sites, residents become better informed about their history and traditions. Understanding the significance of one's heritage provides continuity and context for a community's residents, and it strengthens citizenship values, builds community pride, and improves quality of life [28]. On the other hand Culture heritage tourism - can result in a variety of benefits for local community such as job creation and small enterprise development $[3,27]$. 
Table 2. Marketing strategies to promote tourism in Islamic landmarks

\begin{tabular}{|c|c|c|c|c|c|c|c|c|c|c|}
\hline & $\begin{array}{c}\text { Strongly } \\
\text { disagree } \\
(\%) \\
\end{array}$ & $\begin{array}{c}\text { Disagree } \\
(\%)\end{array}$ & $\begin{array}{c}\text { Neutral } \\
(\%)\end{array}$ & $\begin{array}{c}\text { Agree } \\
(\%)\end{array}$ & $\begin{array}{c}\text { Strongly } \\
\text { agree } \\
(\%) \\
\end{array}$ & Mean & $\begin{array}{l}\text { Std. } \\
\text { Error }\end{array}$ & $\begin{array}{l}\text { Std. } \\
\text { Dev }\end{array}$ & $\begin{array}{l}\text { Chi - } \\
\text { Square }\end{array}$ & Sig. \\
\hline $\begin{array}{l}\text { Accessability of } \\
\text { Information }\end{array}$ & 15 & 39 & 33 & 10 & 3 & 2.48 & .116 & .964 & $33.246 b$ & .000 \\
\hline $\begin{array}{l}\text { Existing of marketing } \\
\text { plan }\end{array}$ & 15 & 39 & 33 & 10 & 3 & 2.48 & .116 & .964 & $33.246 b$ & .000 \\
\hline \multirow[t]{2}{*}{$\begin{array}{l}\text { Existing of a } \\
\text { development plan }\end{array}$} & 13 & 32 & 36 & 15 & 4 & 2.65 & .124 & 1.027 & $25.130 b$ & .000 \\
\hline & $\begin{array}{l}\text { Strongly } \\
\text { agree } \\
(\%) \\
\end{array}$ & $\begin{array}{l}\text { Agree } \\
(\%)\end{array}$ & $\begin{array}{l}\text { Neutral } \\
\text { (\%) }\end{array}$ & $\begin{array}{l}\text { Disagree } \\
\text { (\%) }\end{array}$ & $\begin{array}{c}\text { Strongly } \\
\text { disagree } \\
(\%) \\
\end{array}$ & Mean & $\begin{array}{l}\text { Std. } \\
\text { Error }\end{array}$ & $\begin{array}{l}\text { Std. } \\
\text { Dev }\end{array}$ & $\begin{array}{l}\text { Chi - } \\
\text { Square }\end{array}$ & Sig. \\
\hline $\begin{array}{l}\text { Economic Benefits } \\
\text { to local community }\end{array}$ & 65 & 25 & 6 & 4 & 0 & 1.49 & .096 & .797 & $66.594 a$ & .000 \\
\hline Competitive value & 65 & 20 & 10 & 3 & 2 & 1.55 & .108 & .900 & $95.855 b$ & .000 \\
\hline $\begin{array}{l}\text { Dialogue between } \\
\text { civilization }\end{array}$ & 41 & 44 & 11 & 3 & 1 & 1.81 & .104 & .862 & $95.855 b$ & .000 \\
\hline $\begin{array}{l}\text { Preserves local } \\
\text { traditions and } \\
\text { culture }\end{array}$ & 54 & 32 & 10 & 4 & - & 1.65 & .101 & .837 & $41.783 a$ & .000 \\
\hline $\begin{array}{l}\text { Helps support } \\
\text { community } \\
\text { amenities }\end{array}$ & 36 & 44 & 12 & 6 & 2 & 1.96 & .119 & .992 & $47.594 b$ & .000 \\
\hline $\begin{array}{l}\text { Increases } \\
\text { awareness of the } \\
\text { site or area's } \\
\text { significance }\end{array}$ & 39 & 41 & 12 & 6 & 2 & 1.93 & .121 & 1.005 & $46.725 b$ & .000 \\
\hline $\begin{array}{l}\text { Enhances the } \\
\text { community's image } \\
\text { and pride }\end{array}$ & 30 & 54 & 7 & 6 & 3 & 1.97 & .113 & .939 & $65.420 b$ & .000 \\
\hline
\end{tabular}

\section{CONCLUSION}

There is an increasing world wide recognition of the importance of culture and heritage tourism. Hence, heritage tourism has become a major "new" area of tourism demand that almost all policy-makers are now aware of and anxious to develop [29]. Tourists often visit such historic religious sites as opportunities for gaining cultural and educational experiences [30]. They are seeking authentic experiences that are tied to a specific historic place, rather than just leisure in a resort that could be anywhere [31]. Planning should be used to help provide these experiences, while reducing some of the negative impacts of tourism. Planning can help tourists better appreciate what they are seeing; reduce congestion and crowding by making tourists aware of alternative sites to visit; and explain appropriate tourist behaviors that minimize impacts on the site and its religious use. This study showed clearly that in spite of the fact that the Islamic landmarks is an important part of Egypt's tourism product, but much remains to be done through creative local and regional product development. Developing heritage tourism in Egypt should begin with caring for our authentic historic buildings and sites, and taking the initiative to work with local, regional, conservation and other non-governmental organizations in order to develop a tourism strategy.

\section{REFERENCES}

[1] Cengiz, H., S. Eryılmaz, and Y. Eryılmaz. 2006. The importance of cultural tourism in the EU Integration Process $42^{\text {nd }}$ ISoCaRP Congress.

[2] Richards, G. 2007. The ATLAS cultural tourism project. Available: http://www. tram-research.com/atlas/previous.htm. Accessed July $15^{\text {th }}, 2011$.

[3] Rossitza, O. 2010. Cultural realms: A blog about the business of cultural and creative tourism. Available: http://www.cultural realms.com/2010/01/culturaltourism2010fo recast.html. Accessed September 5 ${ }^{\text {th }}, 2011$.

[4] Helmy, E. and C. Cooper. 2008. Sustainable tourism planning in the Arab World: the 
Egyptian case. Bibliotheca Alexandrina. Egypt, Alexandria.

[5] MacCannell, D. 1976. The tourist: a new theory of the leisure class. Schocken Books.

[6] Tourism Product Development. 2005. Available: http://www.tpdco.org/dynaweb. dti?dynasection=tourismenhancement $\&$ dyn apage $=$ commbased $\&$ dynawebSID $=c 693 c 0 d d$ 0f6f3db0c6f6c206b6d93ee6. Accessed July $10^{\text {th }}, 2011$.

[7] Stebbins, R. 1996. Cultural tourism as serious leisure. Annals of Tourism Research 23, 948-950.

[8] Mclntosh, R. W., and C. Goeldner. 1990. Tourism: principles, practices and philosophies. Wiley, New York.

[9] Zeppel, H. 1992. Cultural tourism in Australia: a growing travel trend. Material Culture. Unit/Department of Tourism. James Cook University, Townsville.

[10] Issac, R. 2008. Understanding the behaviour of cultural tourists towards a classification of Dutch Cultural Tourists. PhD Thesis. Hospitality and Tourism Management, NHTV International Higher Education Breda, Netherlands.

[11] Bernadini, G. 1992. Tourism and cultural tourism in EC policy. In: Provincie Friesland, cultural tourism and regional development, Leeuwarden, 3-5.

[12] World Tourism Organisation. 1985. The states' role in protecting and promoting culture as a factor of tourism development and the proper use and exploitation of the national cultural heritage of sites and monuments for tourists. Spain, Madrid.

[13] Zeppel, H. and C. Hall. 1991. Selling art and history: cultural heritage and tourism. Journal of Tourism Studies 2 (1), 29-45.

[14] National Trust for Historic Preservation. 2011. Available: http://www.culturalherita getourism.org/howToGetStarted.htm. Accessed November 2 ${ }^{\text {nd }}, 2011$.

[15] Hargrove, C. 2002. Heritage tourism. Cultural Resource Management 25 (1), 1011.

[16] National Trust for Historic Preservation. 2011. Available: http://culturalheritage tourism.org/resources/documents/Culturev sHeritage_000.pdf. Accessed November $2^{\text {nd }}$, 2011.

[17] UNESCO. 2004. Dialogue among civilizations. The International Symposium on Dialogue among Cultures and Civilizations Sana'a, Yemen, 1-12.
[18] Salazar, N. 2006. Building a "culture of peace through tourism" reflexive and analytical notes and queries. Artículo de reflexión Recibido University of Pennsylvania 1.

[19] Moufakkir, O. and I. Kelly. 2010. Tourism, progress and peace. CABI, London, UK.

[20] Kris, K. 2011. Islamic civilization. Available: http://archaeology.about.com/od/iterms/qt /islamic_civ.htm. Accessed August $20^{\text {th }}$, 2011.

[21] Islam on line. 2011. A tour of architecture in Islamic cities. Available: http://www.islam online.net/i3/ContentServer?pagename $=|s|$ amOnline/i3Layout $\& c=$ OldArticle \&cid $=1158$ 658332974. Accessed June $9^{\text {th }}, 2011$.

[22] Abou Seif, D. 1989. Islamic architecture in Cairo. E.J. Brill, Leiden, Netherlands.

[23] UNEP. 2003. Tour operators' initiative for sustainable tourism development.Sustainabi Available: http://www.tc.gov.yk.ca/pdf/ lity_TourOpsbestexamples.pdf. Accessed August $12^{\text {th }}, 2011$.

[24] Texas Historical Commission. 2007. Heritage tourism guidebook. Available: http://www. thc.state.tx.us/publications/booklets/HTGui debook.pdf. Accessed September 10th, 2011.

[25] Pedersen, A. 2002. Managing tourism at world heritage sites:a practical manual for preservation in the United States. Available: http://whc.unesco.org/uploads/activities/d ocuments/activity-113-2.pdf

[26] Shackley, M. 2001. Managing sacred sites. Thomson. Channel View Publication. UK, Padstow.

[27] Newman, P. and I. Smith. 2000. Cultural production, place and politics on the South Bank of the Thames. International Journal of Urban and Regional Research 24 (1), 9-24.

[28] Historic Preservation Division, 2010. Heritage tourism handbook: a how-to-guide for Georgia. Available: http://www.georgia. org/wp-content/uploads/2013/09/GA-Heri tage-Tourism-Handbook.pdf.

[29] Montero, J. and G. Aviles. 2010. An alternative to test independence between expectations and disconfirmation versus the positive version of the assimilation theory: an application to the case of cultural/heritage tourism. International Journal of Management and Information Systems 14 (4), 1-10. 
[30] Olsen, D. 2006. Management issues for religious heritage attractions. In Timothy, D., and D. Olsen (Eds.) Tourism, religion and spiritual journeys. Routledge. New York, 104-118.

[31] Macleod, N. 2006. Cultural tourism: aspects of authenticity and commodification. In Smith, M. and M. Robinson (Eds.) Cultural tourism in a changing world. Channel View Publication. Clevedon, 177-190. 